\title{
Some Aspects of Coast Defence
}

\section{Lieutenant-Colonel J. R. J. Jocelyn R.A.}

To cite this article: Lieutenant-Colonel J. R. J. Jocelyn R.A. (1894) Some Aspects of Coast Defence, Royal United Services Institution. Journal, 38:196, 587-616, DOI: $\underline{10.1080 / 03071849109418586}$

To link to this article: http://dx.doi.org/10.1080/03071849109418586

$$
\text { 曲 Published online: } 11 \text { Sep } 2009 .
$$

Submit your article to this journal $\pi$

Q View related articles $₫$ 


\section{Oive dousw}

\section{a \\ Gounal almited Sertite ânstitution.}

VoL. XXXVIII. JUNE, 189.

No. 196.

[Authors alone are responsible for the contents of their respectice Papers.]

Fridas, Fobruary $2,1894$.

Rear-Aduinal II. F. Cleveland in the Chair.

SOMLF $\triangle$ SPECTS OF COAST DLFENCE.

By Lieutenant-Colonel J. R. J. JoceLra, R.L.

TuE tactics of const defence is a wide subject, inrolving much that an enginctr or a sailor is more qualified to deal with than an artilleryman, so that I propose to confine myself to iny own arm; but eren with this restriction, time will not admit of anything like complete. ness of treatment, and I feel obliged to crave indulgenco for a certain want of coherence and continuity that, doubtless, will be detected in my remarks. I would, however, plead in excuse, that coast defenco is no longer an anfamiliar subject, in view of the many excellent lectures that have touched upon it in this theatre, during the last fivo years, and, in addition; that it is possible, I shall hest employ tho time at my disposal, in directing attention to certain points of interest or importance, at the present time.

The fighting units of coast artillery mag be simply stated : the smallest is the group, which should be composed of two or more pieces, ander the command of a group officer; an assemblage of tiro or morc groups constitutes a fort, under a fort commander; while two or more forts, make ap a scetion, under a section C.R.A. All the guns of a group should have the same field of fire, all the groups of a fort should command the same waterway, all tho forts of a section should fire on the same line of approach. There are other ofticers, and other commands and modifications of commands, but this is practically the chain of responsibility, and the object of the organization is to bring erery piece into action, with its proper ammunition, as soon as it can benr on an enemy, to keep it in action till all objectives are disabled or out of range, and to accomplish this cnd as quickly as possible.

roL. XXXXIII. 
Certain subjects connected with this essentially artillery aspect of const defence may bo presented to you, as pegs whereon to hang discussion; they are as follows:- The selection of guns and monutings; the placing of gans; the control of guns; the choice of ammunition; the laying of guns; what we may expect from guns; the action of guns at night ; requirements for training personnel. I do not propose taking them seriatim, but in such order as will most conduce to brevity and clearness.

\section{The Laying of Guns.}

In order to lay a gun correctly, the rango and training which will cause the projectile to hit the objective must bo known. Now no range or position finder in existence, is able to giro us this informa. tion. Something else is necessarg.

The T'liree Service 1 Irthods of Gun Laying.-Thero are three Service. methods of gun laying, known as Cases I, II, and III, cach of which, in turn, becomes suitable, as conditions clange.

Case I.-The tangent scale is raised to the proper height, and the gun laser is responsible for lino and eleration. The position finder (P.F.), or the depression range-finder (D.R.F.), can be employed to measare the distance of the object. The advantages of this nethod are, that it is independent of rise and fall of tide, and is more accurato than quadrant eleration; also from a high site, crrors in range, are minimised by its ase. The disadvantages are, that it depends greatly on the risibility of the object, and personal crror is apt to creep in. As the gun layer is obliged to jump clear before the gun is fired, and as it is more difficult to keep on the object than when only laying for line, it is less rapid than Case II; it is unsuited to salvo fire, and is aw kward at night, on account of the difficulty of seeing the graduations of the scale.

At present Q.F. guns havo always to be fired by this method; it slould bo employed for all guns, when the range is not accurately known, or if instruments break down, or are out of adjustment.

Case II.- The proper quadrant elevation is given to the gun, under the superintendence of the gun captain, while the gun lajer, standing on a sighting step, Inss tho gum for line by aid of straight-edged sights.

The P.F. or D.R.F. can be used to measure the distance of the object. The adrantages of this method are, that tho gun can often be laid correctly when the riew of the object from the gun is much obscured; the dirision of labour, in laying, elininates personal error, and tends to speed and accuracy; it is convenient for salro fire and night work, the gun layer remaining on the step, when the gan is fired, and having no scales to alter. Its disadvantago is, that if the correct range is not known, the resulting error will bo greater than with Caso I. Case II is the normal method.

Case III.-The sights are not used, and the gun is laid by quadrant. alcration and training arc, for what is called "predicted firing." It is only possible with the P.F. This instrument can be mado to pre- 
dict the proper range and training at which to firc, before the timo for firing arrives, this information being exhibited on group dials, which are in electric communication with the instrument. Quadrant elevation is given under the superintendence of the gun captain, while the gan layer sces that the mounting is traversed, nntil its pointer is at the proper position, over the graduated are, on the gun floor. At the proper time, the gun is fired electrically. The adrantages of this method arc; that a gun can be fired at an object totally in risible to, or only seen with difficnlty from, the gun floor, as long as it can be made out, by the telescopo of tho instrument. The invisibility may bo due to smoke, haze, or the way the gun is monnted or placed; the partial invisibility, to long rango or temporary metcorological conditions, such as a hail storm beating in the face of the gan layer. Its disadrantages are, that in general, guns shoot better and more rapidly when laid by aid of the sights, especially if there is any great "displacement" or distance. between the instrument and the group it serres. There are other technical points that I need not touch on. This method wculd be used with advantage for direct long range salvo fire, and, at all times, when guns are specially mounted for high angle fire; occasionally it possesses adrantages at night, and must always be resorted to, when laying by direct vision is inpossible. It is, in every case, a raluable alteruative to the other crses.

Now, in all threc cases, the proper range, and in Caso III tho proper training, in addition, must bo exhibited on the group dials. Either tho P.F. or the D.R.F., when in proper adjustment, can incasture with great accuracy tho distance between an object and tho pedestal on which the instrument is placed; the former can, in addition, determino the distance between the object and the pirot gan of the group; bat more than this is required; the fort commander is obliged to apply certain "corrections" to the information, given by the instraments.

The Poucder Correclion.-Great strides have doubtless been made in the manufactnro of powder, and, if only proper precautions a10 taken in sorting and weighing, very regalar shooting may bo looked for, on any given day, from any given batch of powder; but the strength may vary from timo to time, and generally a correction has to bo made, at any rate at first, until the guns get warm. Wo may. however, note in passing, that bad results are often ascribed to what is called " crror of the day," which are really due to bad adjustment of instruments, defects in loading, and the like. The powder correction has to be considered, with all three cases, whether P.F, or D.R.F. is used.

Tide Correction.- Whereas tangent eleration is unaffected by height of site, quadrant eleration scalcs liare to be made out for each fort; they are constructed, so as to be suitable for the height of the work, abore mean tido; alterations in the level of the latter will sometimes canse sorious alterations in range. The necessary allowance vill increase with the difference from mean lercl, in the height of the tide, and the sharpness of the angle at which the shot strikes the 
water. Other things being equal, low sites and short ranges increase the importance of this correction. It must always be considercd in Case III, and also in Case II, whether P.F. or D.R.F. is used. It does not come in to Case I.

The Correction for Tracel of Objective.-This correction must be considered in Cases $\mathrm{I}$ and II, whether P.F. or D.R.F. is made use of. We will take the case of the D.R.F. first. Before the group officer orders any range to be put on his guns, he must compensate it for the difference between the distances of tho object from the instrument and the pirot gun, and this ho does by applying a "gronp difference," previously laid down, which depends on the displacement and the way the gun is pointing (sec Fig. 3). Inving regard then, to the time, when it will be his duty to fire, and also to the way the range is changing, as shown on the group dials, he gires a certain range, corrected for difference, to his guns, and order's them to fire when the range itself appears on the group dial. But before this can take place, the following course is followed 'The observer' at the telescope, ' $\mathrm{I}$ ' (sce Fig. 1), follows the object, while nnother man watehes the rango drum of the instrument, and calls out ranges, in such a way and at such interrals, as may have been ordered by the fort commander, and in obedience to these calls, a third indiridual noves a large dinl, close to the instrument, known as the fort commander's dial. $A$ fourth individual copies on the group dinl, the movements of the fort commander's dial. When his selected rango appears on the former, the group officer orders his group or gun to "commence firing." "The gun lajers sec that their line is correct, and throw up their arms in Caso II, or quickly fnish their laying and jump down in Case I; at either of these signals, the gun captains involred, order their guns to fire, and the Nos. 4 pall the lanfards.

Next suppose the P.I. is finding the range. Almost the same procedure is followed, except that the group officers liave not to correct for displacement. The observer at the P.F. telescope, T' (see Fig. 1), having manipulated the instrument as ordered by the fort commander, follows the object and the gronp dial exhibits zanges. These are called out, at interrals, by the dial readers, and when the selected range is heard, the group officer orders his group to commence firing, and gan lajers, gun captains, and Nos. 4 proceed as abore detailed. The P.F., thus, sares group difference and three of the operations, necessary in the former case.

The time taken up in this transmission of the range is called the "time of firing," snd depends on the fort and the smnetness of the men.

After the gan is fired the "time of flight" has to elapse before the shot strikes, and both during this period, and the "time of firing" the position of the object inay alter, the necessary allownee depending on its speed and direction. This correction is not required with Case III.

In addition to these corrections for innge, there are others that refer to training.

Training Corrections.-In Cases I and II, cither with P.F. or 


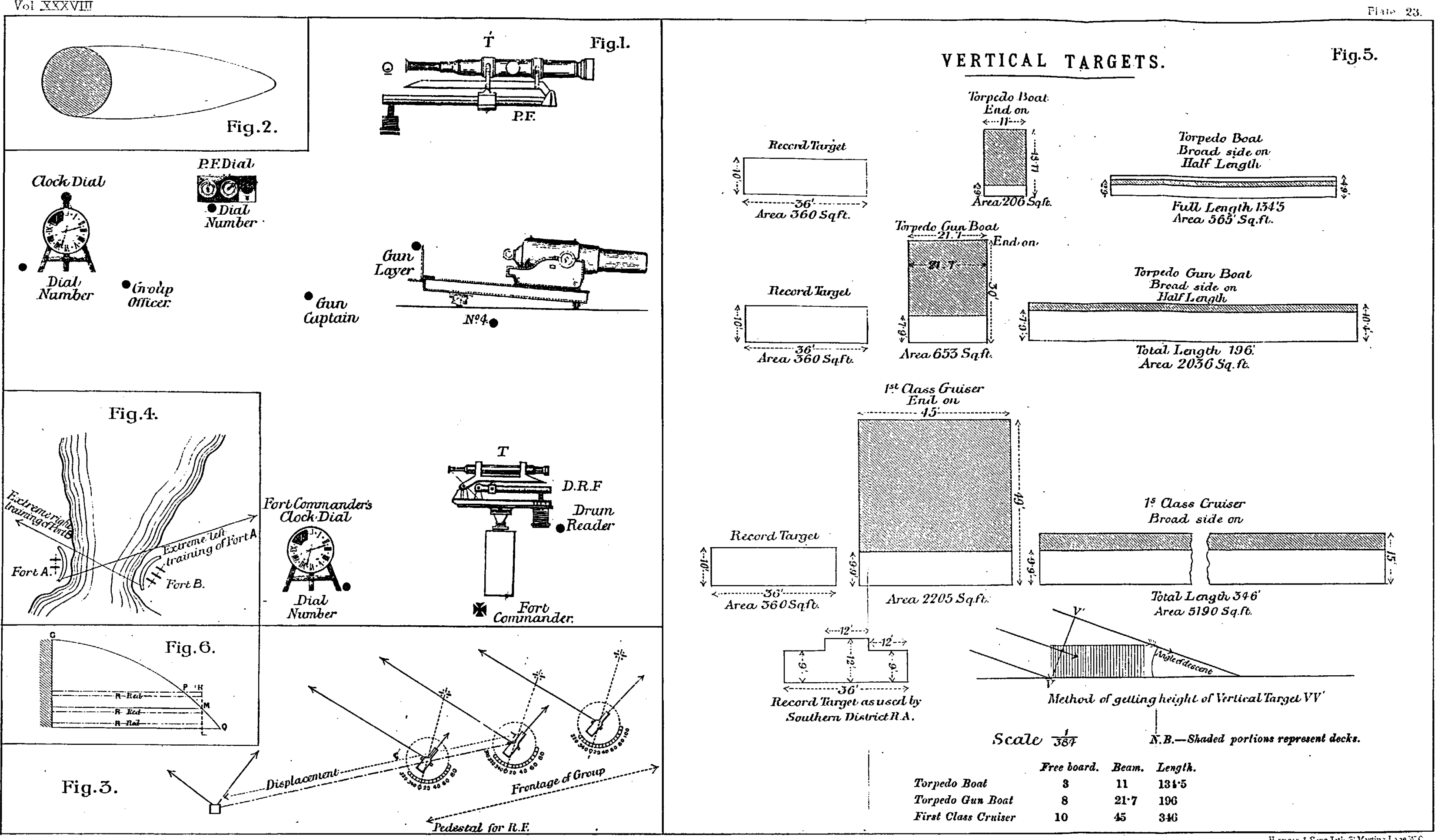


D.R.F., these corrections are made by giving a certain amount of deflection on the lenf of the back sight. They are necessitated by tho effect of wiud and tho angular travel of the object during the time of flight, in Case II, or the time made up of the latter and that taken by the gun lnyer to complete the lasing, in.Cnse I. In addition, if the bow or stern ware is made use of as $n$ lay point, deflection may be necessary, to bring the projectilo to a certain part of the ship. In Caso III not ouly have the aboro effects to be considered, but drift has also to be taken into account, as the gun is not laid by aid of the sights.

The Responsibility of the Fort Commander.-Now, with the exception of the group difference, all these corrections hare to be eraluated and applied, either bs or under the anthority of the fort commander. Not only has the rango to be measured by tho instrument, but the net correction has to be arrired at, and matters so arranged that it is not a distance only, but a corrected distance, that is transmitted to tho group dials. So also as regards training; the gun lajer is responsible cither for the line orer the sights or the position of the pointer, but the fort commander governs the novements of the deflection lenf, or takes measures, in Case III, that the necessary corrections are cmbodied in the transmitted training. No instrument absolres the fort commander from this responsibility; corrections always havo to be made, thes only differ in kind. When fring has commenced, observation is the great aid to correction; bnt the abovo disturbing effects nre not constant in their. infuences, and liave alwiys to be borne in mind. It is unfortunate that bat little real experience in observation of firu can be glenned from our so-called "scrvice prnctice."

The P'osition of the Fort Commander.-Now arises this question: as the correction and observation of fire is so diflicult a matter, how can its performance by a fort commander, be reconciled with effeient and disciplinars control of his mon? My contention is, that the two things are perfectly compatible, if proper arrnngements exist in the work, and if the officer is able to regard matters from the standpoint of their relatire importance for the time being. 'I'be first necessity is a properly chosen station, inside the fort, for its commander, its requirements being as follows: There sliould be a clear view of the waterway commnnded by tho fort; in an open work, gun emplacements should bo in sight, if possible, bat at all times they unust be within easy reach; there should be a pedestal for a D.R.F., an in-. strument that should alirass he at hand, whether the P.F. is installed or not, but the distance of this pedestal from the farthest group should not exceed $200 \mathrm{yds}$., for if it is greater ono set of group differences will unt be sufficiently accurate for all ranges; the station should be roomy, weather proof, clear of the blast of the guns in firing, and bo provided with a table to hold maps and other uscful articles; it should be connected, electrically, with that of the scction C.R.A., while casy menns for communicating ranges, orders, \&c., of the lind best suited to the indiridual uork, should exist between the fort commander and his subordinates. Sometimes two stations of this sort should be provided, cither for the aroidance of smoke or other reasons. In an open work it is often possible for a fort commander to hare the 
greater part of the armament under his eye; in a casemated work, he is bound to be on the roof, but eren there, he is practically as much with his men as if he vere actually on the gun floor, where probably two detachments at most would be aware of bis presence. 'I'he true power of an oflicer over his men is obtained by his methods of dealing with them and their bnowledgo of his character, and the conviction that he will know how the work is going ou, when not actually on the spot. It is only during firing that he necd be at his station, but in action it is no more necessary for him to be looking after petty details of drill, than it is for a squadron leader in a cavalry charge, to concern himself with the dressing of the rear rank. We must demand something from discipline. I put it forward as an ariom, that as long as a fort commander is inside the work, he is in touch with his men.

When the P.F. is being used as the range-finder an apparent difticulty arises, in carrying on the work, from a station as above described, bit it is only an apparent difficulty. In order to obtain the full value of this instrument, it is generalls installed outside the fort, so as to be remored from the elfect of smoke, ${ }^{1}$ and, formerly, it was the invariable custom for tho fort commander to place limself at this olserving station, leaving a sub-commander to represent him in the work. Now it must be understood that each group of guns has its onzl P.F., and the "gifted individuals" who work them are not "trained oflicers of iron nervo and wide experience," but simply young gunners or N.C.O.'s of good eyesight and intelligence, who are instructed as "specinlists," and paid as such ; they are, in fact, glorified gun lajers. Moreover, most works, where the P.F. is installed, have two or moro groups, and as it was impossible for the fort commander to be with more than one instrument at a time, he usually stationed himself in some convenient central position, whence he could see the waterway and communicate with his observers, by roice or orderly, genorally by the latter. There is no reason he should not do, from his station in the fort, all that he used to do at the observing station, and at the same time hare a most efficient control orer the fire.

We bare just commenced to uso portablo telephones, and last jear vers good results were obtained with the Siemens-Halski, when officers were not afraid to nse it. In the past, telephones have been discredited a good deal by bad selection and improper usage. I,ines geldom go out of order; they should be laid permanently, and admit of being tapped readily, terminals being placed at all necessary places. Receivers, transmitters, bells, \&c., should be kept in store, and joined up only when the fort is got ready for action; it is essential that all their parts should bo casily accessiblo to inspection, nothing closed up permanently, and all "gुm crack" fittings forbidden. Telephony has mado great progress in civil life, it should be casy to supply the wants of the coast artillery.

. The essentials, then, are good telephones and sufficient practice,

1 B placing guns and instruments at diffurent lcrels, mist3, peculiar to certain localities, are prerented from interfering with the laying. 
and that being understood, the fort commander should be at no disorlvantage, as far as his observers aro concerned, and be also in the best place for fre control. The method works with the grentest ense, when this officer speaks directly to a snb-commander at tho obserring station, telephone orderlies and all the old cumbrous method, being discarded.

Morcorer, it may sometimes happen, that certain corrections can be better made by a sub-commander at the P.F. observing station, or eren by the observer himself, than by the fort commander. At such times, the latter shonld not hesitate to avail himself of their services; the utmost flexibility of procedire should not only bo allowed, bat bo practised, for, whether it be permitted or not, assuredly the fort commander will arail himself of it in action, not from any want of respect for established order, bat from the force of circumstanees. In making use of the eres and positions of his subordinates he delegates but does not abrogate his functions; he should always hold the strings, for his oflice is to commind, bat, as they say. in the law, qui facit per alium, facit per se.

Gun Layling with Time Shrapnel. - There is a fourth method of laying, which might be emplosed with timo shrapnel agairist quick objectives. It consists in preparing salros of time shell for sereral suitable ranges, following either with P.F. or D.R.F. and firing, when a certain range, corrected as usual, comes on the dial, the gun layers having bept the sights on, for line.' Electric firing from tho P.F. observing station could sometimes bo used with advantage.

Gun laying without a liange-finder.-If tho gun is any leight above the sea, $100 \mathrm{ft}$., say, or vver, a combination of quadrant and tangent clevation serves as a rough rangc-finder; that is, the quadrant elevation, for some rangc, short of an approaching object, is given to the gun, and the tangent scale is run up to the correspoud. ing graduntion, and the gan is fired when the line over the hind sight and fore sight passes through the object. I beliere Colonel French, lato Chief Instructor at Shoeburyness, has been working at a range-finding sight on this principlo; if successful it would appear to fulfil a desideratum with Q.F. gans.

Under this hending of the "Laying of Guns,".I wish to draw attention to the following points :-

1. That the "fighting" of guns in a fortress differs materially from either sea or field service, and points to the necessity for rogimental training.

2. That continual and more extensire practice is required by officers in clioosing the proper methods of fighting their guns and changing, without friction, from one system or "case" to another.

3. The necessity for a common-sense view of the duties of fort commanders, so that they should not be tied down $b_{y}$ pedantic considerations.

1 It is onls at rery short ranges, and ishen the object is morinj swiftly across the guns, that this presents any dificults. 
4. The fallacy of laying down anything like fixed universal rules in the natter of communications.

5. The necessity for experiments to ind a suitable telephone.

6. The proper understanding of the real use and position of range instruments.

\section{The Choice of Ammunition.}

This is, generally, the daty of the for't commander. At one time there appeared to be a good deal of complication connected with this subject; we will soon, I think, be content with vers simple rules, and the first of them would be, that the normal projectile for coast artillery is a common shell with a direct action fuze.

Common Shell.-The efficiency of this projectile is unquestioned; (1) against horizontal targets, at long range, or when fired from guns mounted for high angle fire, especially in salros, and (2) against all unarmoured or lightly-armoured portions of the vertical target. There is, howerer, a point which appears donbtful to some, and which, at all events, would be better for elucidation. Since, in the case of direct fire against a ship carrying any armour, common sbell striking the rertical protection, ncar the belt, would be wasted, our object should evidently be to pitch the shells well ap, so as to secure hits above the impenetrable portion. Now come the questions-How will common shell behave that fall on an upper deck at angles of, say, less than $10^{\circ}$ ? What will their effect be, if burst by striking deck hamper? Can we count on their penctrating the structure to any great extent before they burst? Secing that the deck, especially to guns on a high sitc, furnishes the greater part of the virtual target, as the enemy approaches, the possibility of its efficient attack, by direct fre, is rery important. From this it appears that shells should be as heavy as possible, and it is open to question if it would not at times be wise to adopt reduced charges to ensure a steeper fall for the projectiles.

Armour-fiercing Shot.-With regard to . 'mour-piorcing shot, I think it is fully realized that, unless the armour is vers much overmatched, they should not be used. The comparative immunity the

Huascar" enjoyed, with her $4 \frac{1}{2}$-in. iron plates, against the 9 -in. guns of the "Sliah," has already been quoted in this theatre. Indeed, there appears to me but two occasions when tho uso of the armourpiereing shot is indisputable : (1) When, by use of ligh angle fire, we can make sire of penetrating the horizontal armour of an anchored ship; (2) when battle-ships are pressing homo an attack, and their range and position render their "vitals" vulnerable. 'I'his, of course, leaves out of consideration a lacky shot under the belt during a roll, which, I presume, is a matter of puro chance. Of the above alternatires, the second is not likely to occur often, bnt suppose it were to, it appears to me that eren then, all bat the hearier guns should fire common shell or percussion shrapnel against the deck. perhaps, but certainly against any insufficiently-protected portions, or the rertical target 
Shravnel Shell.-That shrupnel shell, with a percussion fuze, could often be used as common shell, has always been recognised; but, not long ago, time-shrapnel was a discredited projectile; it may be the natural answer to a torpedo-boat attack. It is said that the balls aro effective up to $300 \mathrm{Jds}$. from the point of lurst, but as their indivilnal weight raries in different heary shells from $2 \mathrm{oz}$. to $8 \mathrm{oz}$., it appears desirable to determine by experiment, what is the lightest ball that can be relied upon to penetrate modern torpedo-boat plates up to 3,000 $\mathrm{Jds}$. range, saj. Naturally the lighter the, ball the greater their number, and tho more extended their effect. . The next question would be-What height abovo plane sbould the shell burst to be most effectire against the actual target presented, for I think it would vary with the class and position of the boat. When the balls of a shrapnel strike the water, their "pattern" mas be enclosed in an clongated oral, something like the figure (see Fig. 2.) The relative dimensions of this figuro vary, of course, with the rango and height of burst, but it is found, 1 belicve, that the balls are nuch more closely packed towards the rear, and that about half would fall within the shaded area, which may roughly be described as circular. Fxperiments of this sort could well be carricd ont orer a saud range, and from their results, local schemes could be drawn up, which would depend on armament, waterway, and probable line of attack.

Case Shot.-This is a deadly projectile, at close range, against anything floating that is not nbsolutely protected. However, opinions differ as to its eflicncy against light armour, such as torpedo-boat plates; experiments appear necessary in order to lay down limits of power and range, and also to determine the best sort of ball.

Cartridges.-On mobilization, as soon as a fort is confided to an officer, the largest batch of cartridges of similar brand should be examined and weighed, and the whole of the ammunition should be carefully inspected and arranged, so that by no chance should any alteration in its service take place, without the fort commander's knowledge. Rounds at known ranges should be fired as occasion offers.

Under tho hending of "Choice of Ammunition," I wish to draw attention to the following points :-

7. Can ressels be efficiently attacked by the dircet fire of common shell and perctession shrapnel on their upper decks, and how far can we ntilize reduced charges?

8. With regarll to o:tr oun clefences, are there many places where the close atlacli of latlle-ships is possible or probable, and how far should this affect the cquipment of armour-piercing shot?

9. Hie there occasions where a blow from a solid projectile would bo inore detrimental to an unprotectch ship than a common shell of the same calibre lurst inside her?

10. 'The necessity of experiments to obtain data as to time-slirapnel and case shot.

'These points are numbered consccutirels through the lecture to facilitsto reference. 


\section{The Control of Guns.}

The objectires of coast artillery are either (A) ressels at anchor or (B) ressels in rapid movernent.

Under $A$ may be classed-

(1.) Ships carrying ont, at loncr or medium range, a systemntic attack on forts, or attempting to bombard something defended by the forts.

(2.) Ships supporting by their fire other ships attempting to run past the forts.

(3.) Ships that have anchored at short range to effectually crush forts.

Under $\mathbf{B}$ maj be classed-

(1.) Ships that attempt to run past and at the same tine fire on the forts.

(2.) Ships that attempt to ran past without firing.

Control by Section C.R.A.-In A (1) systematic fire tactics could be opposed to sjstematic attack: careful identification of the enemy would be carricd out, and objectives and even projectiles would bo notified to fort commanders : the scetion C.R.A. would hold a rigid control as long as possible, and distributo his fire to the greatest advantage. The usual installations of telephones and charts, or telephones and indicators, meet the requirements of this service.

In the case of $A$ (2) the control could not be so rigid; the duties of the section C.R.A. would be restricted to seeing that while the supporting ships were kept under fire, the true attack was not neglected.

In case of A (3) taking place, control would have passed into the hands of the fort commanders, as it must whenerer the objectives hare rapid morement; then, control by the section C.R.A. would be liable to lead to confusion.

Looking at what our probable duties in war will be, from a commonsense point of riew, it appears to me that in the majority of cases the duties of this officer will bo more preparatory than executive, but they aro duties of tho highest importance. Apart from those of any military commander, he must see that his section is properly organized and prepared, that ammunition is sorted and ready, that rangefinding arrangements and communications are complete, and possible breakdowns provided for; he must tako especial care to keep himself in touch with coastguard stations, fc. Immediately on mobilization, he would consider tho plans that should have been drawn up in peace time for his guidance, and seo how they should be utilized or modified, in riew of present erents, and then, he should explain to all his fort commanders, as far as it is possiblc, what their action should be, in case of probable erentualities. Here uaval assistance would be invaluable.

Coast defences designed to prerent ships ranning past, would usually have the section C.R.A.'s position well adranced: he would 
thus, when an attack was imminent, be often able to send useful information to his subordinates: during the actual attack he might find it uecessary to draw attention to any ressel that appeared to be escaping punishment, but bejond this he could scarcely go. If the time for interference and non-interference is not thoroughly understood, great confusion might arise, especially if an officer, new to the work, suddenly found himself in command. The telcphone is a dangerous plasthing.

Control by the Fort Commanter. - In the great majority of cases, the fort commander will control the fire of his fort; that is to say, he will exercise full discretion as to when, what, and where to fire, except in so far as he is restricted, either by orders previously giren, or by the propriety of the section C.R.A. kecping the control in his own hands, as abore explained.' Thero should be a normal method laid down for fighting each lort, but the fort commander shonld always be ready to change the "case" or mode of firing, whenerer occasion demanded, and he should have a plan ready, in his head, in case of breakdown in any part of his gear. As long as he is engaging one objective he can kecp the complete control in his own hands, and it is crident, in such a caso as $\mathrm{B}(2)$, when the ships cannot return his fire, be can give his whole attention to the waterway; in special cases, as when guns are mounted for high angle fire, and fought by a P.F. placed at a distance, he would eren leave his men and go to the observing station. The officer responsible for thic fire must sec the waterway, coûte que coûte. But if a fort has to cngage two objectires simultancously, the fort commander can, himself, only direct the fire against one; he must give up the control of the gung engaging the other to some officer, who, in that case, will practically exercise the functions of $a$ fort commander. Each objective engaged requires at least one range-finding instrument.

Under this heading of "Control of Gans," I wish to draw attention to the following points :-

11. In many places claborate meastres for identification and indication of objectives arc uscless, if not mischierous.

12. In each locality, a line of action should be shetched out for the section O.R.A. by superior authority.

13. Schemes of defence should be drawn up of a practical nature, so as to be useful to officers of the ranl: of fort commander, newo to the locality; great advaintages would accrue if there could be more collaboration between officers of the rank of section C.R.A. and C.R.E. and representatives of the Royal Nary, in these matters.

\section{The Placing of Guns.}

The Site.-Efficient protection should always give way to efficient working: both are attainable when a high site is chosen. Tho bigher the site, the more accume the gun, the larger the virtual target, and less bad effect is caused by errors in range or eleration and mistakes of all sorts; deck attack is easier, range fiuding is more 
accarate, and a suitablo place for tho D.R.F. can usaally be found. In fuct, the ranging of guns, when no bigh ground is available, is a difficult matter, not only on account of the unsuitable station that must be given to the fort commander, but also because the special depression range-finder for low sites is unreliable, if not more than 30 or $10 \mathrm{ft}$. alore the sea, unless it is kept in the most perfect adjustment and used for ranges not excecding $2,000 \mathrm{yds}$ ' It is to be hopect that the horizoutal P.F. will get us out of what, at present, is a difficulty. In addition, with a high site, an attack cannot be pressed home, which, we are told, is considered by many sailors tho proper way to deal with forts.

Q.F. gans should always be placed high for the foliowing reasons :They havo often to be fired at an unmeasured mnge; tangent clevatiou and a high site minimize the effects of errors in estimation: the method referred to as Colonel French's can be applied, and may solve a great difficulty. Shots from a Q.F. gun striking the deck of a torpedo-bont are apt to glance, and yet these craft offer an almost horizontal target; now the higher the site the less this liability will be. Mline-fields, booms, \&c., arn often protected by Q.F. gruns on either flank; if the latter are placed near the sea level, as is sometimes advocated, accidents from cross fire may well occur, which could be precented were the guns higher up; at the sea lerel they would also be at a disadrantage, as compared with those on board ship, whereas command would in many cases eusure immunity, at all crents, from short rauge fire. As their trajectory is flat, it is said that when placed low, their fire will have a long dangerous zone; it must, however, be remembered, that their axes uill, as a rule, have to bo at least $5 \mathrm{ft}$. above mean tide, and this, added to the currature of the trajectory, small though it be, will tend to diminish the zone in ques. tion : in addition, all shots that do rot hit the narrow frecboard or small conning tower of a torpedo-boat will probably glance.

Grouping Ginns. - The guns of a fort should be collected into as fer groups as possible, subject to the following conditions: all gans in a group should practically have the same field of fire: they should be of the same calibre and nature, they should not occupy a greater frontage than will admit of their being efficiently orcrlooked by tho group ofliecr, nor must this be of such a length that at extreme trainings there should be any serious difference of range between the flank guus of a groap, all the guns of which are fired at the same range. This frontage should never exceed $10 \mathrm{yds}$. (see Fig. 3). It is also desirable that, when a group has fired its salro, it should be possible to reload and lay, without the detachments being endangered by the firc of neighbouring groups; at extreme tratinings also, individual gans will interfero with each other; this matter should bo carefully considered in designing the fort.

Q.F. guns ought, as a lule, to be gronped clear of a fort; their commander practically exercises the function of a fort cornmander.

The points I wish to draw attention to under this headiug of tho "Placing of Guns," aro :-- 
14. The impcriance, in all cascs, of a ligh site.

15. The necessity for greate: attention to the requirements of group control in placing guns.

\section{The Selection of Guns and Mountings.}

Type of Gun.-Common shell being the normal projectile and shell porrer our priucipal means of offence, it appears to me that, with a certain sum of money to spend, there shonld be a very strong reason indeed for substituting a gan of weaker shell power, for an old t5pe grun of greater shell power. It is, I believe, a fact that a 6-in. I3.L. gun on a II.P. mounting costs the same as a 10-in. R.MI.L. on a barbette, while the weight of their respectire common shell burstingr charges are as $1: 3$, giving the now gun the adrantage of its cast stecl shell. If, now, a cast steel shell were made for the older gun, and secing that effect of burst varies somewhere as the square of the weight of powder, surely, of the two, the 10 -in. gun would be, by far, the most effectire, if the two classes of mounting were both permissible from other causes. MTorcorer, there would be but little difference in the rate of fire.

Monnting. - With regard to mountings, they should be as simple as possible; a little weight or general unisieldiness may be forgiven as - long as they can be worked by hand and do not require much sapervision. On mobilization, we shall have to depend on a good deal of antrained assistance. Our benutiful H.P. carriages I look on, as necessary erils, only to be resorted to from dire necessity.

Guns for High Angle Five.-Likely anchorages for an enemy can most efficiently be defended by guns mounted out of sight, inland, worked by Case III, in connection with a well-adranced observing station. No vessels in existence could remain under an efficient fire of this kind for any length of time. In applying it, range presents little difficulty, but training has to be carefully considered, on account of the great effect of wind and drift. If dynamite guns can only be perfected, they seem to have, here, an ideal rôle.

Q.F. Gums.-In certain places, the newer type hersy Q.F. gans would constitute, of themselres, an efficient defence: they arc simply medium ordnance superbly mounted. In addition to these, howerer, there lias becn a tendency of late to exalt the use of the lighter and mere auxiliars types, at the expense of the ordinars armament. No doubt, as weapons they are excellent, but where shall we get men to work them, especially in the carly days of mobilization, without denuding the heavier guns of their detachments? In the hands of untrained men Q.F. guns are worse than useless. I nm also of opinion that many of the objects they are supposed to fulfil, could bo equally or better carried out by case or shrapnel. I do not believo in firing them into baze or smoke to "sweep" a watermas; there would be a certainty of great waste of ammunition and a probability of considerable danger. They hare their place, no doubt, but should not supersele, to any great extent, the lieavier guns : they should be on cone mountings and be fired from the shoulder; field carriages arc 
unsuitnble for const work, and mobility would only be a source of confasion, especially at night. Coast artillery has no mobility, it must depend on its long arm and its heavy blow.

Case-shot Guns.-When it is required to cover with mitraille, the neighbourhood'of a boom, the opening of a harbour or a mine-field, close at hand, special guns, to fire caso shot, are an efficient means of defence: if on opposite sides of an approach, they should be mounted with trarersing stops to prevent any chance of their firing into each other. Sce Fig. 4.

Tho question of choice of gans is a large one, and, to a certain extent, outside the scopo of this lecture, I, howerer, wish to draw attention to these essentially artillery aspects of it:-

16. The desiralility of heavy shells and sinple movintings.

17. The dificulty of cficiently manning a greal number of Q.F. guns and the possibility of the guns of the forts themselves performing many duties, apt to be assigned to the Q.F. guns.

18. The use of case-shot guns for protecting vaters vilhin short ranges.

\section{What may be expected from Guns.}

Possible Accuracy.-Gunnery in peace has the following adrantages over gunnery in war:- The nerre strain of battlo is absent : there are no casnalties : there is no surprise: there is no fatigue: the work is seldom done in really bad weather, and scarcely ever at vight; observation of fire is not interfered with by any confusion, as to where a certain shot comes from; the objectire is nerer hidden by smoke, and, on account of the danger, practice is nerer carried on, when fog and haze exist; ranges change so slowly, en account of the speed and direction of the target tugs, that the difficultics of corrections for travel, do not crop up and are not realized. On the other hand, as each round is so cxpensire and consequently so few are allowed, all firing has to be carefully ased for instruction: detachments nerer fire a largo number of shots under the same conditions; obserrers, gun lajers, methods of firing, \&c., are continually being changed : the targets fircd at aro small as compared with ships, and real rapidity is interfered with, from safet-j considerations. While there is thus sometbing to be said ou both sides I think tho great difference between peace and war should lie fally realised, and I, for one, would be rery loth to form in my own mind any ambitions theor's; at the same time, I feel that the porrer of the guns is apt to bo underrated.

I haro myself seen some excellent results at a Hong Kong target, going 8 or 9 knots, such as 20 rounds, fired from five guns in $7 \frac{1}{2}$ minutes, all falling inside $n$ virtual target, $12 \mathrm{ft}$. high by $30 \mathrm{ft}$. broad; and last year the whole of the practice in the Isle of Wight, some 500 rounds-practice which was chiefy instructional, and sometimes carried out in a way that precluded accuracy for line-gare us one hit in every three rounds, on a target $12 \mathrm{ft}$. high by $31 \mathrm{ft}$. long. Howercr some of these results come under the head of "calculated hits;" that is the line and the longitudinal error were observed, and the hit was detcrmined; by tho known angle of descent. Discredit has 
sonetimes been thrown on this manner of scoring, so I will put some results before you, which were obtained on a record target, actual hits only being allowed to connt. The target was $36 \mathrm{ft}$. long, $12 \mathrm{ft}$. high in the middle, and $9 \mathrm{ft}$. high, for a distance of $12 \mathrm{ft}$. at each end. (Scc Fig. 5.) It was so heary, that it had not a greater specd than 5 or 6 knots, and ranges changed but slowly, giring an arerage of 2,200 gards. Against this target six companies of the southern district, carricd out their competition practice, each company firing on a different day. They together furnished 6 fort conimanders, 6 range-finding detachments, 22 group oflicers, 4 detachments, and consequently 44 gun captains and gun lagers; of the last, half wero chosen by the officers commanding companies, and half were determined by lot from the registered lajer's of the companies. Each company fired 16 rounds from 4 guns; one weak company only furnished 4 detnchments, so that each of these fired 4 rounds; but in the other cases group officers and detachments were changed after each had fired turo rounds only; half the rounds were by single gun and half by group salro.

'The weather on the six days raried from windy and rainy days to almost perfect ones, and from those again to days on which there was a dazzling glare in the gun layers' eyes.

The firing took place from Sandown Fort, an old casemated work whose interior arrangements were very defectire; the guns wero 10-in. R.MI.L., $30 \mathrm{ft}$. above the sen. Case II and D.R.F. were cmplojed, the instrament being on the roof, about $45 \mathrm{ft}$. abore mean tide. Reduced charges were used, which, according to tho rango tables, reduced tho accuracy, very nearly 50 p.c.; at all everts there was no doube that the rind had considerable effect on the high trajectory. 'There was, occasionally, interference from smoke and fouling of ports, but the arerage of the actunl times taken by each company, was $12 \frac{1}{2}$ minutes. Of the 06 rounds fired, 4 were hits upou the target. For the sake of comparison, I have put to scale, on the figure (see Fig. 5), the virtual targets presented by this record target, and by a lst class torpedo-boat, a torpedo-gun boat, and a cruiser, taken from tho "Naval Annual."

Eiject of Smoke.-A great deal has been said about the effect of smoke in obscuring a range: it is of course all a matter of wind, or rather the absence of wind; a gentle breeze blowing down the range is the most annoying; thus, one of the companies above referred to, was stupped for $2 \frac{1}{2}$ minutes, owing to tho slowly moving smoke, drifting in the same direction as the target. But as far as this went, there was only one bad day in the six; a liigh wind soon clears off the smoke: I have seen, in some night operations, tho effect of barrels of pitch, being lighted on a ship's deck, so as to enclose her in a reil of smoke; dense clouds rose up all round her, and though she was passing through an area, illuminated by many thousands of candle power, we could see absolutely nothing of her hull. We, however, knew her range, approximately, from lier position in tho channel; for now and again, we conld see shadowy lines, which we knew to bo her masts, and we could easily havo fired on her with effect. I think the effect of smoke is apt to be exaggerated. 
Under this heading of what wo may expect from guns, I wish to uimw attention to the following points :-

19. May we not now claim that in daylight, with, well trained men, actual hits on a target representing a ship, should be numerous, in view of the experience detailed above, where many of the conditions zere the veverse of farourable und the target so comparatively small?

20. Is it not now time to qualify that oft.quoted and very sicecping dictum that "for ships to run past forts, uhere no obstacles exist, is a comparaticly casy mattcr"?

\section{The stction of Guns at Night.}

Respectable opinions vary greatly as to what can and cannot be done by an enerny, under cover of for or darkness. It is, I fancy, rery much a question of locality, and here, the gaidance of our naval confrires would be inraluable in drawing up schemes of deferce; for the brain of an ordinary landsman reels in presence of the many exc cathedri $(i$ statements tliat are made.

Flectric Lights.-The question of electric lights is in an unsatisfactory state. There was a beautiful theoretical simplicity about our carly iden, of noting ressels as they passed through $n$ fixed beam, and passing them on from light to light, the whole being controlled by the section C.R.A. This would be a patent method for rendering torpedo-boat attacks casy. The creation of a large and brilliantly illuminated aren, which was also tried, might work well if a ver's large number of pieces bear upon a narrow obligatory place of passage. It seems to me, however, impossible to make certain of stopping, at night, a swarm of torpedo-boats, gallantly pressing home an attack, by defences at one portion only, of a channel. Where tho defences have depth it is a different matter, the adranced guns putting those in rear on the qui rive. What nmount of depth of defenco will render a channel securo is, I fancy, at present doubtfal; it rould depend, in a great measure, on the answers to some of the questions already referred to. From what I have seen of night operations, I am convinced that, as a rule, search lights are more conrenient than fixed beams. Colonel Wathin's dials have giren us an excellent means of controlling them from any station, but as a rule I shonld prefer to see them normally under the fort commanders, subject, of course, to any orders the section C.R.A. may gire. We should, howerer, not leare the arrangements for electric lighting to bo settled under the pressure of inminent war. It is no easy matter to place them safely to the best advautage, and the present uncertainty is a serious cmbarrassment to the preparation of practical schemes of defence. It is of course a matter of expense.

Flectric lights might be supplemented by parachute lights, fired from mortars. Tho or three specially constructed morturs of small weight, placed at a fort commander's station, might give him the menns of keeping bis front illuminated, during the progress of a 
torpedo-boat attack. This could easily bo determined by experiment.

Illuminated Sights.-This is also a pressing question; there are many technical reasons why Case II is better than Case I at night, so electric gun sights should be of the straight-edged pattern. A contrirnnce of this sort was unofticially tried, with success, at the Isle of Wight two years ago; there does not appear to bo nny difficults about the matter.

An illuminated tangent sight is a necessity for Q.F. guns: we had a modification of the naral sight in use, but wo found that it was impossible to lay, with a full sight, as by day. 'This is rerg important from our point of view, and a simple alteration was proposed by onc of our assistant instruciors, Sergeant Kirby, recommended and sent forward; I have not heard of it since. It would also be well if the elevating wheel of this sight could be manipulated by a man, other than the gun lager; so that the latter could kecp his line, while the clevation was being altered, either by direction of the gun lajer or the group oflicer or fort commander. It would also secm desirable to experiment with combined quadrant and tangent elevation, as before noted. On many nights in the year you can lay perfectly with electric; sights, without search lights or other artificial illumination; on many occasions their absence renders the guns uscless. It is a technical matter, and, in my opinion, they are a crging necessity.

Microphonic Detectors.-If these instruments can be perfected they would render the defence, by case-shot guns, an ensy matter by night.

Ilentification of an Enemy and IRules of Iraffic.-The mensures to bo taken at night, to distinguish between friend and foc, hare, no donbt, been thought out for each locality. It woald, however, be wiso to familinrize officers with the procedure that will be in force in war, or, at all events, to let them think it over. At the present moment, tho question "What am I to do if I see or hear a swift objective approaching?" would be a matter of considerable embarrassment to many fort commanders.

The points I wish to draw attention to under this heading of "Action of Guns at Night," aro as follows :-

21. The necessity of the immediate placing of the E.I. question on a more stable lasis, and of experimenting utith parachute lights, \&॰c.

22. 'The necessity of providing and practising with electric sights.

23. The necessity of the junior ranks, being accustomed to realize in peace the procedure that will be followed in war, as to the identification of approacling ressels.

\section{IRequirements for Training Personuel.}

Companies of Royal Artillery.-Individual training has its uses, bnt by far the most raluable kind is that, whero officers and men work together in units. Tho late improvements in this respect are well kwown, as far as the Garrison Ârtillery is concerned; but it is very difficult to carrs ont efficient training with the piesent allowance of

vol. XXxillu. 
ammunition; there is, howerer, little likelihood of its being increased. The panacea is the establishment of practice batteries, so organized that 64-pr. projectiles can be fired by all the different mothods and cases. But this must in no way interfere with familiarizing all hands with the forts themselres.

It is not the actual firing of a fow guns in a fort of any size that effects this; a group of guns is practically the same thing, whererer it is placed: what really is of value, is the testing the communications and range finding arraugements of a work, and a rers great deal can be dono by manning, as for war, witliout actually expending ammunition. Testing of mountings and familiarizing men with them is fully net by "station practice," but the larger works, often from lack of men, often from barrack accommodation being mixed up with gun floor's, have, in certain respects, to be neglected, with the result that no one knows how they should be fought.

Nititia Artillery.-The training of the Artillery Militia has relatiscly adranced pari passu with that of the regulars; they now settle down quickly into. a fort, and usually do rery good work; it is, howerer, often the case that in each brigade there are one or two officers, who seem to absorb the greater part of the good of the trainincr, leaving a residue who do not attain to anything like the same efficiency. Now in a fighting force we want a good general areragc. It also is a pity that no mcans seem to exist, for keeping up the knowledge obtained, periodically; but, speaking generally; in the Drilitia, we have a magnificent reserve.

Volunter Artillery.- The training of the Artillers Voluntecrs has not progressed as it might have, and this is certainly not the fault of the Voluntecr officere, who so freely give us their mones, time, and intelligence. But there las been for this force, as far as I know, no training of the unit, which is the only real training for Coast Artillery. Some of the officers may hare seen, as fron a Pisgah, a laud flowing with rango and position finders, but the greater part of the force are still in the house of hondago, trying to make bricks without straw:

There is no doubt that officers of both Militin and Voluntcer Artillery want more help in their training. 'l'ho literatare of a new subject is not always easily understood; the tools of the trade require to be handled, and, perhaps in the past, there has been a little orey elaboration, so that many an anxious stadent has found himself in the position of the man of Ethiopia, who when asked by the Apostle "Understandest thon what thou readest?" replicd "How can I, except some man should guide me?".

The points I wish to bring to your notico are-

24. The necessity for practice batterics.

25. The desiratility of testing the communications and the handling of our larger ivorks.

26. Facilitics for Militia officers to keep up their lsnowledge betucen trainings.

.27. That the Volunteer Artillery, whom we shall have to depend on in 
the early and dangerous days of mobilization, should have more oppoitunities for practical training, and more ammunition to five.

When the Council of this Institution did me the honour of asking me to read a paper on Const Defence, I was very pleased to accept the in ritation. 'Three Fears' expericnce of a practice camp has convinced me that the efficient service of the gans of a fortress is one which cherishes and produces the highest military gualities : smartness, coolness, self-relinnce, and discipline; and I find, in the subject of Coast Defence, much to admire, much to interest, and much to learn. Our present position is accurately represented by a clover little picture, by whom I know not, which wns supposed to show the state of the Field Artillery. In it, a ganner stood firmly planted on the Rock of Progress, but his boots were still encumbered by the mucl and slime of the Slough of Despond, ont of which he had struggled. In the distance towered the Peak of lerfection, bat his road, even to its base, was barred by a jawning chasm, the Abyss of Fads. Still the drawing was full of hope, for orer this ugly gulf was thrown, a strong plank of Common Sense.

Hajor F. G. Stoxe : I rise with some diffidenec, as a junior offiecr, at the commencement of this discussion. I nm sure we must all fecl grateful to Licut.Colonel Jocelyn for giring. us the benefit of the latest ideas on the question of const defence obtaining at our most highly ralued camp of instruction. Colonel Jocelyn's nrrangement of "pegs" on which to lang discussion is a rery happy thouglit upon which I congratulate him. I am glad to ece that as regards "laging" the adrantages of Caso II are fairly giren; in adrocating the use of Case II whencrer possible the lecturer is reflecting the opinion of evers practical const gunner that 1 hare met. As regards the position of Fort Commancler-for I obscrre that the familiar term is adlicred to, as opposed to "Fire Cowmander"I cannot quite agreo with tho lectarer that in Case III the Fort Commander should be in tho Fort. I tako it 23 an axiom that Case III would nerer be $\mathrm{cm}$ plored winere Case II is possible, therefore when Cuse III is adopted it implies that there is difficults in the obserration of the target from the Fort. The responsibilitics of the Fort Commander are clearly laid down in the lecture, and it is diffeult to ecc why these responsibilitics should be delegated to a eub-commander in the Fort Commander's P.F. obscrring station, in order that the Fort Commander may renuin in the work and be nominally in touch with his men. I will quote the lecturer's own words in support of my argument. "In netion it is no more necessary for him to be looking after petty details of drill than it is for a squisdron leader in a caralyy charge to concern himself with the dressing of the rear rank." Tho rery conditions which render Cise III necessars, instead of Case II, appear to me to be so many arguments in farour of the Fort Commander being in the 1'.F. obscrring station in order to nssumc the higher functions of command, delegating the mere superrision of the details on tho gun floors to a sub.commander. "Gun laying withont a range finder." Under this head the adoption of a wellknown principle is adrocated: this principle has been ingeniously worked out practically by Colonel Frcach. I hare had some cxperience of this derice, and cannot concur in thinking it suitable for Q.F. guns : it is too slow in operation, depending as it docs on a succession of predictions and being non-continuous as a range finding instrument. I teliero that $Q$.F. guns will find their range much more rapidly by trial shots ; this, howerer, could easily be prored by trial. I belicre I am redecting naral opinion on this matter. I beliere the best range finder for $Q . F$. gun is the Q.F. gun itsclf. Of course any range finder or position finder which might gire npproximate range, if it happens to be landy, would bo of great ralue in order to detenaine the cleration for the first round. Under the head "cartridges," tho following statement is made: "Rounds at bnown ranges slould be firal as occasion 
ofers." Mas I suggest to Colonel Jocelyn as an amendment to this, "Rounds rith a time fuze should be fred as occasion offers;" in other words, let us get some data as to how our fuzes will burn before going into action, 3 if wo begin firing time shrapnel at a moring object without such data, our fire may be wasted. The eubject of time shrapacl is a difficult one when considered relatircly to a noring target. The plan of loading certain guns with slirapncl, fuzed for a certain range, can onls mect the rery simplest casc, riz., that of ships being compelled to keep a certain course without deriating much to right or left; in other words, running through a channel. It is, moreorer, somerhat wasteful of armament, as it amounts to holding certain guns in reserve for a special phose of the light when their fire might be raluable all through the fight. The subject is somewhat screrely "let ulone" in the drill book. It is not stated who is responsible for length of fuze or correction of fuze, nor liow correction for different groups in the sanc fort, firing at the same target, can be carried out. To $m y$ mind the best was would be for one or two trial rounds to be fired, that is before tle action commenes, and the Fire Commander, or F.C., to gire the necessary correction for the day, e.g.-" 10 per cent." That oricr gocs to all the group oflicers. The control of the shrapnel fire at a moring object should then naturally fall to the group officers who would set. their fuzcs according to the gromp range at which they intended to fire their next salro, wlen orders hare been giren by the F.C. for shrapnel firing by group from right or left, as the case might be. The F.C. could assist the group offecrs by informing them of the position of burst so that a further possible correction might be made in the setting of their fuzes the nert round. I cordialls ngrec with the lecturer as to pey No. 15. The opinion of the C.R.A. ought to curry great weight in the selection of sites, \&c., in order that this requirement maj not he lost sight of, that is to say, grouping the guns, making your sito with the view to get the largest number of guns into the group, and at the eame time not. extending the cuns on either side more than the minimum nmount allowed by Colonel Jocelyn as a requisite which would rers likely be lost sight of by anj but an artillers offecr accustomed to euperrise the fighting of forts. I cannot agree wilh the lecturer in his strictures on the crtended emplojment of liglit Q.F. guns in opposition to the case and shrapacl fire from heary guns at torpedo-boats. I hare trained detachments to use Q.F. guns, and have no besitation in eaying that their manipulation is much more readily learnt by any int elligent non-cownissioned oflicer or guu-laycr of Volunteers than is the more complicated serrice of a 10-inch R.IL.L. gun, taling ns it doss a detrehment of $15 \mathrm{mcs}$. There is an immeuse siring in the number of men required, which in another was Colonel Jocelyn made a great point of. You can do the same work with far ferer guns. There is no tendence to flurry when engaging a rapidly moring object, inasmuch as the layer knows that if his first or second shot does not hit there is no barm done, since the third and fourth will probably fall on the target, and from the nature of Q.F. guns he can follow that target with a continuous running fire which can be lept up and corrected with case the whole time the target is xithin range. This certainly is not the case with the heary gun, where he practically puts all his cggs into one basket, riz., the basket of that one shot. The tspical gun for rork against torpelo-boats appears to mo to be the 1-pr. Iarim witli automatic action. This gun is not,in our serrice, I beliere, though I cannot understand why it is not introduced, it being in ercry eense the most cconomical and cficient weapon for the purpose ndrocated.

Colonel F. T. Lrord: I cordiully agree with Major Stone in culogizing the system which Coloncl Jocelyn las adopted of giring us certain pegs on which to base our discussion on the subject which ho has so ably brought before us this afternoon, because I think it will kecp us from dwelling too much upon what I cannot help calling the fads of artillersmen, which I am afraid are rers numerous. Among the number of points which Colonel Jocelyn's lecture raiscs, I must select one or tho of the more prominent. The position of the Fort Commander is a rery important question, and oncthat I hare always liad rers much at heart. I am told by artillery offecrs that if the F.C., as he is called, does not put himself on the gun foor with his men, he will lose all control of them : they will not think rery mueh of an ofticer who does not slare their danger and their kork. My riew of a F.C. is that he has to fight his guns to the best of his ubility, and in order to do that, he 
must place himself where he can best obserre not only the effect of his own fire but the action of the attacking force, whether ships or men. All other considera. tions must give way to that most important duts. What will suit the Islo of Wight will be rerg unsuitable, perhaps, for Garrison Yoint Fort, or the new defences at Alen, Malta, or Gibraltar; nud, ngain, the treatment of tlieso inuat differ from such a line as that connecting Southsea Castle with Eastncy Fort, where we have a number of G.in. I3.T. guns spaced rery widely, and where ilere are exceed. ingly difficult questions of command inrolred. As to gun laying with tiwe shrapnel, I really do not think that that is a rers effectire projectile against any probable attacking force. I do not quite sce how you are to decide at what point it will be best to open firc; and jou hare also this diflicult, that jou huro half a dozen guns lnill with diderent lengths of time fuzes, nnel at different clerations, and if sour ressel docs not come within the range of those clerations and the scope of those time fuzes, sour guns are practically spiked, they are uscles3; sou cannot draw the charge, because of the gas-check. - A system of that eort cannot be a suceessul one. We had better rely in these cases on quick-firing guns. As to the use of shrapnel generally, itluat must depend upon the nature of the target, for time shrapnel, eren by das, would probably be uscless against anything but boats. I think percussion shrapnel or even unfuzed shrapnel maj be used with effect at moderate ranges, against unarnoured ships and the unarmourcd portion of armourcd ships, and they would be a most valuable projectile. With refercace to the priparation of a scheme of defence, Coloncl Jocelyn sass: "In cach locality a line of action slould be sket ched out for the section C.R.A. br superior authority." There I am rather at issue with him. IIe says " shetched out," and I daresay he only means hinted at; but $I$ think that the section C.R.A. is the man on whom should derolre the preparation of those sebemes of clefence, and that those schemes sliould be most carc. fully thouglit out by the local authorities, who must not allow themselres to be too much hampered by so-called gencral principles: I say with a full senso of my re. eponsibility that the local authorities mest hare a free hand for erery work of defence, and unst, in short, work out thcir orn salration, in conformity with, but not in subjection to, general principles. They are the responsible people, and on them should derolre the scheme of defence. Injor Stone dealt with objections to Colonel Frencli's process of range finding. One of the great objections to it was that in the caso of hears guns, the sume process had to be repeated erery time the gun was fired, on account of the recoil. If it lad not been for that, I think his suggestion was a rery raluable onc. Now, a word or two about the selection of guns and mountings. Colonel Jocelyn compares the G.in. B.L. gun with the 10-in. R.JI.L. gun, and Eo far as the porrer of their shells is concerned, of course I agree with him, but I think lie must take into consideration not only the reight of slicll that can be poured in in a giren time, but the localities in which it is proposed to place these hydro-pneumatic mountings. Ther are intended mainly for low sites, where in the presence of Q.F. guns, 10-in. R.MI.L. guns, whether firing through ports or open embrasures or en barbette, could hardly be used in the pre. sent day; their detachments would be obliterated in a rerg short time; therefore these hyclro-pneunatic mountings are forced upon us, but should be reserred for low-site batterics. I now go on to point 20. "Is it not now time to qualify that oft-quoted and rers swecping dictum that for ships to run past forts, where no obstacles exist, is a comparatively casy matter? "I do not think I am guilts of a breach of confidence if I allnde in the most general manner, of course, to a confidential document which has just been issued by that rers autinoritatire bods, the Committce on Naral and Jilitary Defence. Thes deal with this very subject of ships runuing pist forts, rers brictly and rery wuch to the point, and I think thoso kho are interested in that matter could not do better than study the decision which is there laid down as to that rery point. The gist of it really is that ships will not run past forts unless they can obtain a space besond the forts out of gun fire, wide enough to turn in, in order, I presume, that they mal run back, so I think the cases of running past will not be of rers frequent occurrence.

Colonel Jocenrs: Is the probability of their running past discussed in the paper?

Colonel Lrosd : No, but they will not attempt to run past unless they can turn 
in an undefendecl arca. Colonel Jocelyn suggested parachule lights for night work. I do not think they will be found rery entisfactory. Parachute lights here been uscd, as ererybody in this thcatre knows, for many ycurs past, up to a large calibre, and the objection to them has been that the nren whicl they liglit is reas sasall, and that the light thrown orer that area is but a mere glimmer. Thes liare been prettywell abandoned, both for the defence and attack of fortresses, and hare becn supersedcd by star-shell. Before learing the subject altogether, I think it would be well if some of the distinguished officers present would be willing to throw some light upon the following points that $I$ hare atill to touch on. We must consiler first, when arranging for const defence, what would be an oncmy's object in approaching any point of our shore-I do not say the shores of England, but the shores of any part of our limpire. Theso objects can be rers briefly specified. First, the acquisition of a port or fortress as a neral or military base-tiat corcrs a great deal of ground; eccondly, for raiding purpoees, cither by torpedo-boats ofcruisers: and, thirdly, to enable them to land at an unprotected portion of the coast. line, in fact, for inrasion. Now, tho consensus of opinion gencrally points, I think, to the teaching that the naries of forcign Powers will make no attempt on any of our fortificd places so long as they are thorouchls well manned and armed. We shall hare no recurrence in this country nor ut any of our coaling stations, I trust and belicre, of the experience of Alczandria in 1852. I think that mas practically be dismissed so long as we keep our armaments up to date und our men drillecl. But raiding by torpedo-bonts a ad cruisers is highls probable, and will be a grcat feature in the war of the future. The third object is landing at an unprotected portion of our const line is possible, but unlikely; but anj one of thesc may be fored upon a forcign Gorcrnwent either from political necessity or some popula. morement, so that we may consider that we have to face the posibilities of erery one of them. As to the first of them, what we require nost for our port 3 is tlie protection and the perfecting of our communications-telcgraphic, telephonic, whaterer they mas be. Thes are not costly; they bear no sort of proportion to the cost of our forts and guns and stock of ammunition, and jet they are not perfected, and rery slow progress is made with them. Then the provision of the cheap adjuncts which are required for satisfactorily working a system of guns, whetler placed in a fort or in jsolated cmplacements; and, lastly, we want more clasticity in the echerac of defence. I do not think it does to lay down-aud Coloucl Jocelsu mentioned this-any hard and fast rules as to the position of a Fort Commander or details of that bind, which ought to be settled on the spot. We want elasticity; wo rant the F.C. to be supreme in his district. The scetion C.R.d., as he is called, is the officer who initiates the whole thing, who plans the scheme in ccnjurction with his ndrisers, and the F.C. is the indiridual wio carries out tirat scheme. 'The rection C.R.A. is a purcly consuitatiro and administrative officer, and has practically nothing to do with fighting the guns, cxcept to gire the F.C. such information as comes to his knowledge. That is $\mathrm{my}$ riew of it. Inother thing in which wc fail is rapidity of firc. Our artillery fire is far too slow. We must encourage, bj erers possible means, rapidity of fire, and rapidity of firc cannot be insured nithout those adjuncts of which I spole just now. It is lisrdly necessary to insist upon the nccessity, but if we consider for one moment the adrance of artillers ecience and the progress of ecience generally connected with stcam porer, quick-firing gune, and so on, what would hare done very well 30 years ngo, when we had GS.prs. as our best arnament, will not do now when we hare 6.in. Q.F. guns. As to the question of torpcdo-boats and other craft at night, I am afraid we are tcrubly bebindhand. No satisfactory scheme for stopping torpedo-boats going up a chennel has jet been derised, and it would appear that we must rels for etopping them on some gort of mobile defence, in fact we must rels upon the nars. I cannot Bee at present that any arrangement which we have made from the shore, except in corcring rers narrow chamncls, has beca the least satisfactory. I cone last to the landing on our slores, and I hare onls a word or two to say on that point. Our policj at the present time is that in case of an attempt at landing on our shores, our forco is to be concentrated in inland positious. I think the principlo of that is excedingly good, but it should not be enforecd to the cntire exclusion of the occunation of the coast line. On my part of tho coast, in the South.Fastern 
District, we hare, as you all hnow, a rery extengire scries of Martello torers, and I cannot belp thinking the ancient mnsonrs of which those towers are composed rould prove a rerg effectire obslacle to anything but very heary gims. They aro not very large, and on the greater part of that const, as you nre nell aware, large ships cannot come in close to the coast line. Frery resscl that came in close enough to fire at them monld lare to bo of rery small dratght. I do not think we must depend the least in the world for prolonged defence on these towers, because they could bo breached or talien b5 assault, but thes might be.utilized b5 laring a Q.F. gun and a machine-gun mounted in cach of them. They should hare a garrison of about 7 men. I liare worked out the prime cost of arming the number of Martello towers which are arailable fo: this purpose, and it cones to something like $150,000 \mathrm{l}$, incluting a stock of ammunition. That is not a rers lorge expicuditure, and I think for the sake of delaying, if only for 2.1 hours, the adrance of an enems inland, something sliould be done to check them at our frontier. That 2.4 hours would be of incalculable ralue for purposes of mobilization, and for the concentration on tho inland positions of the large force of legulars und auxiliary troops which wo expect will be placed there.

Coloncl RICHARDSO: : It is rather difficult to criticise a paper with which in the main Jou agrec. The chief difliculty that $n$ Iccturcr on const defence mects is the fact that one general system does not suit the requirements of crery locality. It is rers natural for anybody who writes a lecture to found general principles on his own experience, but his own crpericuce, as a rulc, is onls tiut of a fer places, and tberefore it is rery difficult to dogmatize. In eome minor instances I disagree with him. Ife lajs down that all the grouns of a fort should command the same watcrway, and all the forts of a scetion should fire on the same line of approach. How docs he reconcile this axiom with the cuse of the breakwater fort at Plynouth, which fires orer two waterways? With Caze I, ho says, fire is more accurate than with quadrant eleration. I feel lie is tulking only of the serrice method; but I maintain quadrant cleration might make sbooting perfect. What we want is a hydro-clironoweter which is eimple, which lias largo dirisions, and a morable scale and zcro to compensato for tidle and powder crror. 'lhat, you might say, is a rery difficult thing to get, but I hare ecen that sort of hydro-chronometer. Captain Donohuc, I.O.MI., produced one some sears "tgo. It wins quite in the rough, but some little practice took place with it, practico of most jemarkable accuracy. Again, the lecturer eags, "quadrant firing is only possiblo with the 1.F." I think it is quite possible that with any R.F. good results might be obtained. I ani glad to ece Colonel Jocclyn has adopted the term " Fort Commnnder." As to their proper position, we get a difference of opinion. IInjor Stone and Colonel Hlogd both think thes ehould be well aras from their men, but I cannot sce the slightest difficulty in their being generalls insido their forts. Thes can control the firc cqually well and ret be with their men, so near them tlint they can at any time risit them. I lare seen no difficulty about it nnywhere, csecpt in the case of high angle fire, when 1 think.F.C.'s must be as near to the target as they can be, so as to ece fire effect well. The lecturer lays down that there should be a pedestal for the D.R.F. I think there ought to be inany of these D.R.F.'s in evers fort. It docs not follow that jou are only going to cngage one ship. In peace practice we fire at only one target, or at most at two. Te have not rery manj men, and the consequence is we are apt to think that one D.R.F. is all that is requircd; but some groups will be silent because there are not enough D.R.F.'s in our forts. I am rery much in accord with the lecturer as to his ideats of how communications sliould be rorked, except perliaps on one or two miner points. As to the pegs he gires us on which to hang discussion, I agreo with the principles of rers nearly all of them, and merely propose to touch slightly on thuee vith which $I$ caneot quite agrec. The first is fo. 5 , where he speats of the neccssity for cxperiments to find a suitable telephone. I cannot lielp ashing, Wly telephone? because the telcphono is a rery bewildering instrument, at the best, in wind or noise, and I think we haro found that the telegraph, or perbaps tho printing telegraph, is better. I quite agree, howerer, that somo experiments should be carricd out to find out the best instrument for our wants. Then as to the clioico of ammunition, he sass the normal projectile for const artillery is a common ebcll 
witlı a dircet action fuze. The common slell is certainly the normal projectile, but 1 think, if we do have a direct action fuze, it should be slightly delayed. 'There is no difficulty in that, because fuzes with vers great delas hure becn produced. In No. 7 he asks, "Can ressels be efficiently attacked by the dircel fire of common shell and percussion elirapnel on their upper decks, and how far can wo utilize reduced charges?" Our object is alnass to cripple a ship, and not to kill a fer men. We want reall 5 to break up or sink the ehip itself; the men must follow, und therefore we should not use reduced charges. Some people think shrapnal should be used against unarmoured slips, but it is unlikely that shrapnel will cripple a ship so much as the rery large charge contained in common sliell. Admiral Clereland has ecen quite lately common sliclls fired causing frightful destruction behind plates, quite enough man.billing effect without a few weak ballets added to it. Then with regard to No. 8, I suppose there ought to be a few armour-piercing elint, in case any ship pas foolish enough to come up close and engage a well found fort, but othernise I do not think there is any place rbere sbips will attack us at rers close ranges if we are properls prepared. It is all going by theors, but it is diflicult to conccire an instance in which a solid projectile striking an unprotected ship would do as nuch harm as 20 or $30 \mathrm{lbs}$. of powder or ligh explosive bursting inside lier. Then we come to No. 10 . I do not know tlat time shrapnel in the ordinary sense w ill erer suit our purpose rery well. Of course I suppose the lect urer means for use agninst torpedo-boats chieffy. This brings in rather a large question, rlich necessitates a good deal of thought. The nars hare elceted to meet the attack of torpelo.boats with Q.F. guns, but I am not quite sure whether Q.F. guns are the best for coast artillery purposes. I should libe to ece this discussed instead of the mere question of time shrapnel. I have heard opinions cxpressed in the nary that the mere peuctration of the outer skin of a torpedo-bont will not stop it; it is too big giume to be stopped by small shot, sou want a big smashing bullet for it. 'That I do not know, but I think, both in the const artillery and in the nary, each man holds his own theoretical opinion, for want of real war expericnec. In many cases of narrow clannels, rapid-firivg case guns would probably be rery awkward tlings for torpedo-boats delajed by booms or oflicr obstacles. Some of the cnormous number of hits must nrore effectire. The lecturer appears to have touclied raller lightls on the most difficult problem with which coast artillergmen lare to deal. and that is tho defence (which Colonel Lloyd laid eome etress on) against torpedo-boat raids; that is the only thing we liare now left to proride against if our heavg nmmanents are kept efficient; but here again we line not real expericuce to guide us. I nns rery anxious a little while ago to start a small torpedo-hont-opposing scliool, but I unfortunately could not get the funds to do it. W'e should hare learnt a rery great deal if we liad deroted ourselres to producing extremely swift moring torpedo fargets, perhaps corering them with eome eort of light armour, and trging what we really could do by night and day. We might liarc found, perliaps, that the Q.F. Gun is the best defence. I do not think the navy yet realize what will lappen in an engagement where torpedo-boats come on quickly, how in the act of self-defence thes will peg away into cach other with these Q.F. guus, which have rery long mage. I know we const artillery will not be long allowed to fire into opposite eheres, into towns, \&c. Under the head the "Control of Guns" No. 11, he says, "In many places claborate measurcs for identification and inclication of objectires are uscless, if not mischicrous." I think that in all places if these means are too intricate thes are misclierous, but in most places a simple oystem, such as Captain Orde Browne has been good enough to work out for us, could not do harm, whether you use it or not. No doubt some will use it, and I hope we sliall get it issued soon. "In cach locality a line of action should be skctched out for the section C.R.d. by superior authority." That line of action is laid down fairly well in our drill book. 'The ecction C.R.A. ought to be an offecl of eotne considerable experience, and if he is too much tied by rule he won't act at all. Then the lecturer sajs in No. 13 that "Great adrantoges would accrue if there could be more collaboration between officers of the rank of section C.R.A. and C.R.E. and representatires of the Rojal Nary in these matters." The result would be the const artillergmen would hare a great many adrisers. I hare 
a good mang friends in the nars, and I get a good mauy different opinions from them. Are we to have one scction working one way and another tho other way, according to the opinions of their respective naral adrisers? I do not think that is desirable. The best way is for the C.R.A. to be in comununication with the principal naral authority of the district and then gire his orders. The C.R.d. of the district must be the head, he must hare ererything under him; it won't do for each junior to go his own was. Then as to Nos. 14 and 15 , I hold rery strong opinions. I thint the lecturer is rers sound throughout, especially in laying stress on a high site whererer it can be obtained. There are lots of places wilucro we eec high sites arailable for all-round fire, and a lower site choren. 'There is some mention made ahout the automatic sighting of Q.F. guns. There are sights already inrented that wonld do rery well indeed, if made practical; they only want rorking out. If anshody will make the trunnion eight morable instead of the tangent sight, he will see how rers casily an automatic sight can be derised. It was.first suggested by a Voluntecr oflicer, Captain Grant, a very clerer man, some Jears ago, and I cannot see at all why his ideas should not be cularged and adapted to range finding with Q.F. guns. It mould be perfectls autounatic. On this system, whenerer you laid the gun correctly on the object the gun was ready to fire a shot at the range required. It is a very promising idea where high sites are arailable. I agree with the lecturer about the utilization of old guns. I suppose lie was thinking of G-in. H.I. When talking of substituting guns of weaker slicll fre for the old type guns. Many of our old tspe gums are slow in firing, but they are cheap and nerer get out of order. I disagree with Major Stone that the Yoluntecrs cannot work them; I think they work them rers quiekly and rers well.

Major Stove : I did not impls that at all. Wintat I suid was it is easicr to train a detachment with your quick firers than the detuchent of a 10-in. gun which consists of $1 \overline{5}$ men.

Colonel Ricrsibsox: The R.F. gun takes rerg long training, and an enormous number of rounds must be fired before you can expeet the men to hit; whereiss with the 10-in. anybody can shoot well. We do not get much ammunition for 10.in., but we make rery good practice. Oring to its two motions the quick-firer prores very difficult to any man, cren though he is a good lityer with ordinary gune. Fluborate guns will certainls be sooner out of order than the old simple wenpons. Then about Q.F. guns, how thes should be placed. 'Lhe lecturer sajs thes sliould be on cone mountings and fired from the shoulder. With that $I$ quite agree. They sljould be cone mounted, put on a truek, to more where jou like to selected posilions. He says "Const artillery bas no nobilits." Iou can get it in that way; we could bring ans number of Q.F. guns to any required spot. We find that thes fire very well from trucks. Fou liare only to run a railway round about the works and you hare rerg considerable mobility. I am glad he las called attention to the ill cffect of enobe being exaggerated. I am a rers strong adrocate for snokeless powder, but snoke docs not so tery often interfere with shooting. Then about fhips running past forts. I belicre history will always repeat itsclf and sbips will alwajs hare the power of running rast foits. It is ouly a question if the defences are rery cflicient; if they are, eliphs will not do it without recciring a rers grent dcal of damage, and will thes run the risk of losing a rery large fraction of their power for nothing? What are they going to do when they get by? Are they going to run into a lot of eubmarine mines? I do not think they will attempt to run past except in fairls open cliannels. As for electric lights, we want crperience. The emall, tritling trials that we have had hare tanght us little; but I agree with the lect urce that search lights are far more effectire than fixcd beams. I quite agree with hin that search lights for the fighting of a fort should be under the F.C. ercry bit as much as bis guns. On the question of illuminated sights, I seo lie lints that they must be electric sights. There is a great craze for electricity; it is to do crerything; but I hare a sort of idea that the simplest sight, and the best, would be one perhaps in which electricity lad nothing whaterer to do. Tho thing we want is not so much an electric sight as a perfect sight, wihich can be nltered in its brightness eo as to suit different states of atmosphere. We want comething we can use effectircls bs night. I quite agree that on wany nights jou cau lay perfectly with ordinary sights, without scarch lights or any artificiul 
illunination. I go further. I believe there are very few nights in the sear in which you could not las guns without the clectric light; and there is one form of liglit. ing up a channel that nerer secuns to hare been noticed, that is putting lights on the far side of it. Jou can sec a ship perfectly well in sbadow, and you can use the range finder. The lecturer thinks the subalterns, or the jounger officers, the junior ranks should be aceustoned to realize in peace the procedure that will be followed in war as to the identification of approaching ressels. Well, there used to be a good old rule that hardly erer failed. It has etood the great test of war. Fire a shot aliend; if the slip stops she is probnbls frieudls, if she docs not let her iare it. She will either stop hersclf, or we shail stop her. The necessity for practice batteries I quite agree with; we ought to hare more practice batteries, becauso of the difliculties of our home ranges, but I would not hara a praclice battery at all if it had the effect of prerenting us practising from serrice butteries. Then there is "The desirability of testing the communications and the handling of our larger works." It one place the lecturer lias made the etatement that nobody knows how some of these large works are to be handled. I have a fair experience of our forts, but I do not know where this state of things exiets.

Injor F. IR. Fiysile, R.A.: As regards the Fort Commander's corrections, Coloncl Jocelyn has enumerated, seriatim, a formidable number of these, for tide, for trarel of objectire, for powder, for time of Dight, nud so on. 'These are doubtless all necessars, but $I$ should like rery carnestly to put forward that to attempt to treat then cach as scparato corrections is somewhat wislcading, as practically these rarious corrections hare to be merged into one at any giren moment. The attempt to treat them scparately is rerg discouraging to officers who have to be Fort Commanders-as it induces the feeling that the task is moro diflicult than it is in reality. The offecr should make his corrections on secing where his projectiles are falling, without reference to what may be the exact causc or causes of an crror lie secs. If when firing ut a moring object ho secs his projectiles strike besond and behind his object, he should simply correct his range and deflection, instantly and boldly, by what he cstimates as the amount of tho error, and carry on the firing without a pause. This plan sares a lot of time, and $I$ am sure if it ucre almass put in that way, we ehould train our Fort Comnanders quicker and casice than we do at present, for it is confusing and discouraging for n man to feel that he has such a lot to think about at criticul mowents. Sccondly, secing that corrections are unsoidable, I should efrongly adrocate taling up the subject of applying them mechanicalls. It is rers difficult for anjone, howerer well traincd, to apply these corrections in his head, and this is a weak point in our system. Tt can bo done mechanically, and if our authoritics will only take it up as a subject to be considered, I hare no doubt that a rers good result could be arrired at. One other point is that Colonel Jocelyn apparently expresses a preference for the lieary shell of the 10-in. IR.JI.L. on the grounds that it is a bigger ehell. 'lliat is perfectly true, and the gun is a good gun, but in these dass when the objectire is likely to be under fire such a vers short time, it surely is more important to fire with rapidity. Fou mas waste tro or three shots from tho rery best gun, and rapidity of fire is probably more important than a great big shell which is wasted if it does not hit the object. Fourthly, as regards fuzes, which hare been mentioned in the discussion, I cannot think that time fuzes, used as sucl, can cres be rers manageable in const artillers work. 13ut it is rers important to be able to expend your shell, if possible, after ricocliet, to prerent it clamaging friends, so if some time action could be appended to the dircet action fuzo so that the shell, if it misscd the object, would be crpended automatically at long range, it night simplify the matter of cross firc in narrow channels. Laetly, about Q.F.guns, there is no doubt that the rate of firc is, in theso dass, of the higluest inportance, and the move their command is simplified the beltes. I quite agree with IIajor Stone iliat the proper range finder for the Q.F. gun is the Q.F. gun itsclf : these guns should also, as put forward by Colonel Richardion, be used in groups of a mobile nature, that is to 825 , the guus rould bo triusferred to different points. If you tie yourself hand and foot with erers gun in a fixed position some attack of an unforescen nature may find a weak spot. If tho lighter Q.F. guns are properls mounted, and morable, we elall hare in our lands a great 
power for defence. The effect of a group of four 6-prs., well handled, is rery grcat, and it nould be a rers good thing if we wero supplied with nore of these for coast purposes.

Colonel C. II. Cozes : I should like, ns a Toluntecr artillersman, to sas n few words, especially as an officer who lias not only "stood on the top of l'ism. " but has also entered into "tho land flowing with runge and position finders," and to say I thoroughly endorse the suggestions made by Colonel Jocelyn on the subject of training the Volunteer artillery. Althougl the Toluntecr artillery commenced to learn the duty of coast defence immediately the Red Book was issued, still a coursc at one of the scliools of instruction cnables us to grasp the spirit of the system at great deal better, and I would recommend such a courso to any officer who can spare the time. The idca of 6-1-pr. practice batterics and more ammunition will commend itself to all, especially to those brigades which are stationed near sea ranges, but in places like London, where we are 50 miles from a fractice batters, the difficulty of trarelling expenses comes in rery hearily. The Gorernment only grant trarclling allowances on one occasion for ono man per annum. I would, with rery mucli deference, with regard to the training of artillery, offer tho following suggestions :-In the first place, that gums of the same nature that the Folunteer artillery are called upon to man in tho forts generally-9-, 10-, and 11-in. gunsshould bo issued, say, in the proportion of 1 to 300 men; those guns should be complete, sith mountings, fittings, \&c. 13y this means much raluable time would bo saver bj instructing the men in gun drill at their own drill stations, thercby enabling the unit to procecl at once with tho drill scrics or scrive practice when in the forts. My contention is that it is realls a wasto of raluable time to have to instruct Yolunteer gunners in the drill of these guns in the forts, the drill of which they ought to learn at their own drill stations, but which at the present time they are unablo to do, because tho guns aro not fortheoming. Let us harc a certain uumber of guns complete; thes may bo dummy guns, but let the mounting 3 and fittings bo complete, so that the men inay bnow them thoroughly. Sccondly, with regard to London, where there are 2,000 garrison artillerymen, I would suggest that Tilburg fort should be more utilized us a drill station. I think Voluntce. artillery companies might go down there five or six times in tho jear nnd carry out. the drill serics of the competitire practice, and possibly the annual gun inspection of the companies might tako place down there. Thirdly, that in the practice which is carried out at Sheerness the firing should be as nearly as possible in accordance with the regulations for Serrice practice. I think these suggestions might be adopted witbout incurring large expense, and the ideas of the lecturer, with which I agree, might be made thoroughly workable.

Colonel Jocerry, in reply, said : It is rery late, and if I pass rapidly over the points rarious officers hare raiscd it is from no want of fecling that there is a great deal to be said about those points, and some of them I should like to take time to amplify if possible. I rould like to touch, howerer, upon one or two things, because I hare been misunderstood as to $\mathrm{ms}$ phrascologs, and first, with regard to what Mrajor Stone has said about the F.C. being in lis obserring station and carrying out corrections of fire; what I want to say is that the F.C., when he goes into his fort, locs not know perlinps rhether ho is going to use Caso I, Case II, or Ciss III, and he outht to be alle to usc auy ono at any moment as the necessity urisce. In order to do that I do not think there is any causo for him to be in the fort. I nerer had the opport unity of sceing Coloncl Irencli's sight, and I bow to what Colonel Stone and Colonel rlosd harc eaid about it. I merely drew attention to it becuuse I thought the laying of Q.F. guns at night, whero the continuous R.F. is not always possible, unight solve what uppeared to us all the other day a grcat diliculty. Then with regard to the Q.1. guns; I myself do not know rerj much. Major Stone said you cun do the sance work with them with fewer gune. If he meant to say that you could do the same work witl the Q.F. guns that jou could do with the heary guns I should like to know what le meant. With regard to the training of men, thero is no difficulty whaterer in training Volunter artillery to work heary guns when you have specialists existing in all the districts to do the epecial work, such as lasing und so on, and I think it is mucle casicr to train men with hears guns thun with Q.F. guws. With regard to mhat Colonel Iloyd said, the whole point of ms lecture 
was that what suits ouc place mas nut suit another. I am deal against tying donn anjbody. With regard to the ecction C.K.L. and the preparation of the scheme of defence, what I meant was that I hare seen the mere fact of a man being supplied with large charts, with groups, squares, \&c., has a tendenes to make him interfere with the F.C., to gire him objections, and to.say, "What equare are jou on ?" which is uscless in a channel or in any place where there is an casier and specdicr menns of identification. I think Colonel Orde Browne's work with regard to what he has done for shipy is most raluable. I did not incan to underrate it for a single instant; all I meant rras, if you put a lot of tools into the hands of a man who is rery npt to play with them, thero may bo danger. I think some oflicers rill under. stand what I mean. I know the luydro-pnenmatic carringe is forced upon us with some low sitcs. What I meant was I should like nlwass to use the hears slecll when I could get it. With regard to rapidity of fire from 6 -in. and 10-in. guns, I myself do not think there will be nuch difference. I hare not had much experience with hydro-pneumatic mountings, but did I understand it would be slowcr firing with the 10-in. than with the 0. iu.?

Colonel Irrord : Yes.

Colonel Jocelry : I bow to your opinion, because I haro not had much expericnce.

Colonel Lrord: I an sorry I cannot gire jou the figures.

Colonel Jocely: : 'Thero is a great deal to be said for that, and $I$ at once adurit that rapidity of fire is of the lighest importance. I think we ought to bear in wind the ralue of a lire she!l, that is what I meant. Then there is a point that Colonel Richardson mentioned with regard to deprecating naral adrico to the scetion C.R.A. and the section C.R.IS. Ife know that oflicers commanding artillery stations liare the benefit of this conrersation with Admirals and so on, and they secm to derive a great dcal of beneft from it, and I cannot ece why the junior ranks should not benefit in the same way. I only once in ing serrice had the opport unity of close connection with the nary und tho linginecrs, all combined in the same operations in the Isle of Wight. It lasted for four or fire days, and I learned more in those four or fire dajs than I did in four or fire jears at nny other time. I found it of the greatest use to hear what they liad to eas and to discuss matters with then. With regard to the roobilits of wnchine-guns, of course Colonel Richardson and Afajor Elmslie hare both spoken from what thes have eecn ns to moring guns on trucls. 'There nug bo many cases in which that is excellent, but I hare not ecen it. I am only judging from my own point of riew, that ruuning about with Q.F. guns in the night nas possibly lead to confusion. I lo not want to dram any comparison between shrapnel and Q.F. guns, execpt in so far as this, that I do not think wo know what shrapncl will do, and I merely want to haro some experiments to find this out. I do not think I liare been understood by some officers. '1 hes thought I was going to load up the gun and wait for the slip to come. A F.C. would hare to use his wits. If he saw ships prepuring to run through be rould be perfectly certain to get the range. II could use his gun for other purposes until that time came. It docs not take long to order guns to be used with shrapsel for a certain range. Then, with regard to correction, I do not think ansbody will accuse us of frightening F.C.'e, for it is our object to make crersthing as simple 9.9 possible : and as far as doing it mechanically, I hare written a paper in our orn proceedings about that, which is merely another peg for somebody to sec what can be done in putting on corrections for speed mechanically, because in certain forts the corrections are very important; and I do not quite go kith MIajor Elmslic in sajing jou cun corrcet from one shot to another, bceause the conditions clange. I hare a casc in point. Here is a gun $14 \mathrm{ft}$. aboro wean tide, the corrections for tratel are from 5,400 to 1,000 : they vary like this, $-125,-95,-50,-25,0,+5$, $+25,+50,+100,+125$, all on the eaule line. I do not think jou can shoot well if jou do not consider these thing separately. There is the result of two corrections, and I do not think at all erents the F.C.'s of tho Southern District would feel that they hare been in any way bothered by correction. If sou can do it nutomatically by all means do it. Captain Cranipton, the gunners instructor at Cork Harbour, wrote the other day about an automatic time correction, and I should rery much like to sec it tried. I $\mathrm{am}$ all for doing ererytbing automatically and 
making things as simple as possible. The only gist of my lecture was that what are merely matters of theory stould be supportod by practice.'

The Chsinkas (Admiral Clereland): It now derolres upon me to cloze the discussion. I suppose I ought to gire a sumunry of the criticisms which hare been

1 Witl regard to the discussion that has taken place, I should like to make the following remarks. As to Colonel Richardson's criticism on my definitions of the "fighting units," I am amare that they were not quite coupplete. MIs object was to strite the caso as briefls as possible; a section may sometimes hare to deal with two lines of approach, just as two fields of fire may be commanded by tarious guns in the same fort; but one S.C.R.A. and one F.C. can only dleal with one of these things at the eame time; should a section be simultancousls attacked from tro lines of approach, the S.C.RA. rould hare to delegate the charge of a portion of it to a subordinate, and if a fort is obliged to fire, simultancously, on two fields of fire, there must be practically two F.C.'s. This is what I meant by "modifieations of command."

Under the heading of lasing of guns, I gare an account of certain corrections. It appeared to me that $\mathrm{Xnjor}$ Elmslie misunderstood ms object in doing this ; I wished to bring out the real use and position of our instruments. I lare alwajs tried to eimplify the duties of the F.C.'s. It the same time I feel sure that no peace practice brings out the real dificulties that mas occur on service in correcting fire.

When I said tlat "predicted firing" was onls possible with the P.F., I meant that this was the only Service method.

Colonel Llogd objected to tho firing of shrapnel time shell, as described in the lecture; it may, howerer, be worth experimenting witls. I do not thint the guns should be loaded until a suituble objectire is in sight; but, in a given clisnnel, certain obligatorj ranges can be selected, and the shells got reads for loading. If the objectives were sunt, or turued bach, before thes reached the range the guns were prepared for, the latter can always be fircd off and the shells got rid of that พaร.

As to Colonel French's sight, I hare onls heard of it, bul nerer seen it. I cannot help thinking it would be useful, witl: Q.F. Gung on conc mountings, in certain places.

Witl regard to 3lajor Stone's remarks about the position of the F.C. when using 1'.F. Cusc III, I can only sas that I think he should be in the fort then, as at most other times, if it was only in order that lie mas be able to clange from one system of firing to another, as ocession mag arise. Flexibility of procedure can only thus be obtained. Quite apart from this, there are other rers important considerations which demand his presence there.

As to choice of projectile, I am rery sorss no naral officcr gare us the benefit of his ndrice.

With regard to tho control of guns and identification of objectires, I by no means meant to underrate the raluable work Captain Orde Browne lias done; on the contrary, I think it should be carefully st tudied by nll onfers of coast artillery. $3[\mathrm{y}$ meaning was, that somewhat complicated means for fire control would be better absent from a section C.R.A.'s station, when from the nature of the case such control rould not be possible in action.

With regard to choice of guns, I mished to cmplusize the importance of heary shell; the exnmple I gare was intended to start a discussion. I fully admit the importance of rapidity of fire, and it is always insisted on in the Isle of Wight; at the same time I think, as a rule, tro salvos of 10 -in. shell would be more effectire that three of 6.in.

I know the question of Q.W. guns tersus shrapnel is a rery rexed onc; my object ras to demand crperiments with the latter; tho data on the subject is, as far us $I$ hare hecn able to asccrtain, rers meagre, and tho decision as to which is best is much too important a one to leare to theorctical diseussion onls.

I mentioned parachute lights, as I had seen their trial recommended by at least two oflicers of experience; I was sorrs to hear from Colonel Lloyd that his crpesience was dead against them; at all crents the star-shell might be tricd. 
bestowed upon this ablo paper, but $I$ do not intend to do so. The tine is late and the subject matter too technical. In all the lectures on this subject which I liarn heard or read, there appears to be one reakness, that is, the authors do not seem to have a very definito idea what the nature of the attack upon our coast defences will be. IIf opinion is, that so long as we hold the supremacy of the eea (and. I hope we ehall nercr lose it, for if we do, no amount of coast defence will sare us), the most probable nature of attack against which the forts gunrding the approaches to our naral roadsteads should be alirass prepared, is the sudden and continuous rush of torpedo-boats; I do not think you will get angthing more formidablo than that; and it is to meet that particular form of attack that $I$ should like to see souve definite and seltled plan of defenee. Whether it is to be met, as Colonel lichardson suggests, by firing casc-shot from heary gurs or by Q.F. gung, is a technical question, but one that certainly ouglit to be definitely settlecl. With your permission I will tender your thanks and the thanks of the Institution to the lecturer for tho rery instructire lecture that he has giren us. 

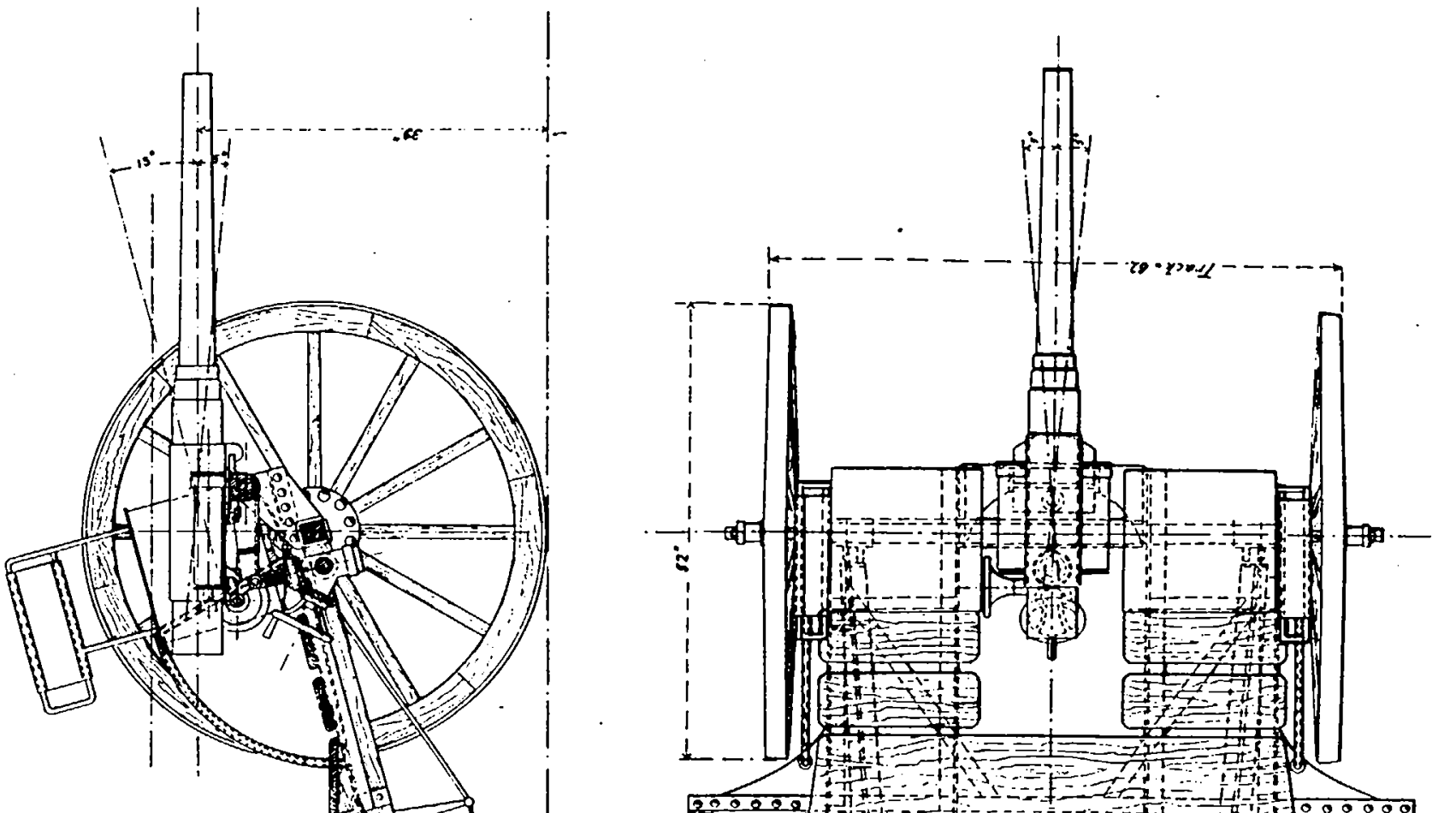

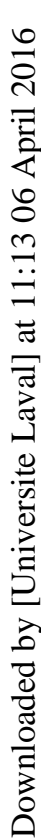
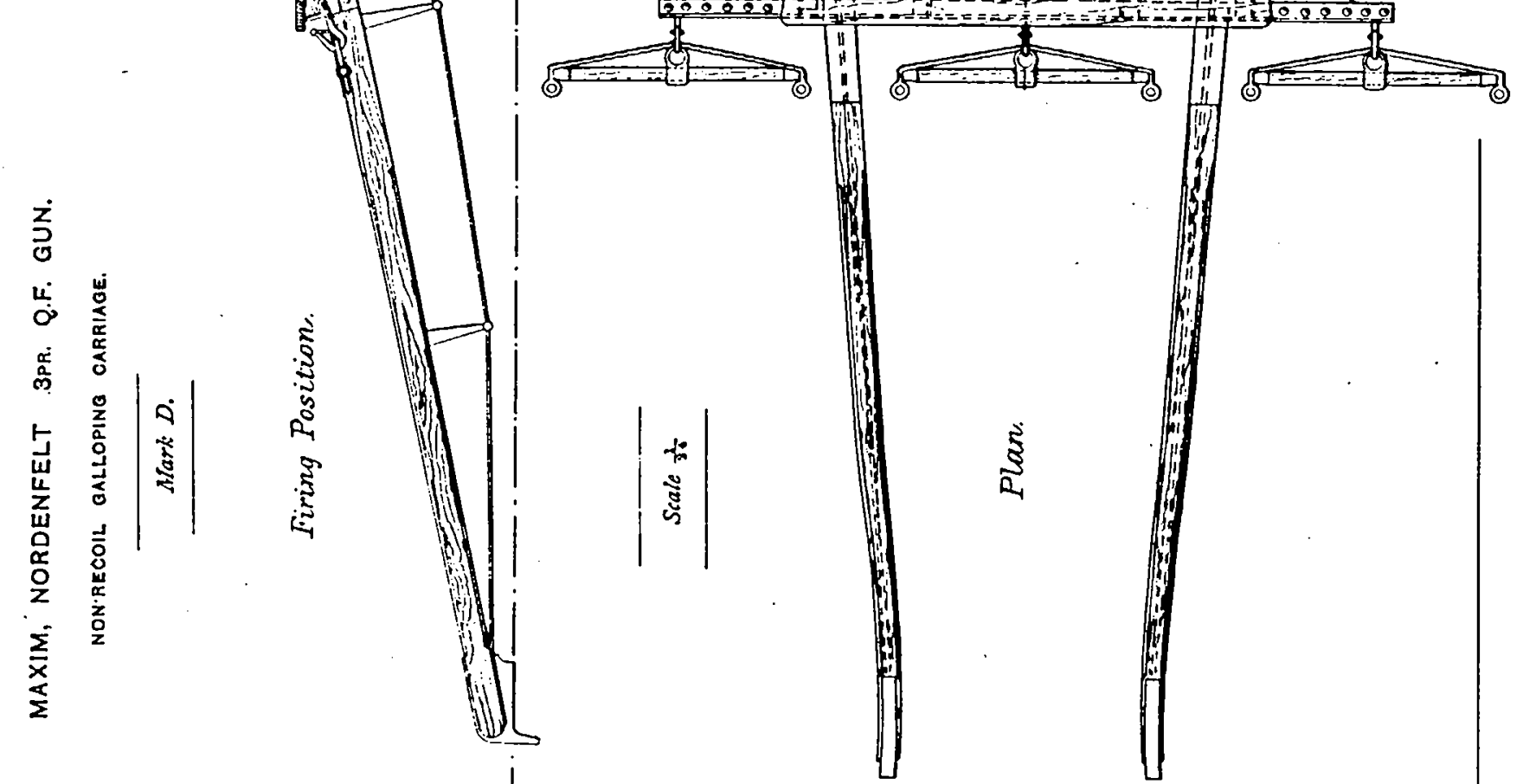